\title{
Changes in Juvenile Salmon Prey Fields Associated with a Recent Marine Heat Wave in the Northern California Current
}

\author{
Elizabeth A. Daly ${ }^{1}$, Toby D. Auth ${ }^{2}$, Richard D. Brodeur ${ }^{3}$, and Kym C. Jacobson ${ }^{3}$ \\ ${ }^{1}$ Cooperative Institute for Marine Resources Studies, Oregon State University, Newport, Oregon 97365, USA \\ ${ }^{2}$ Pacific States Marine Fisheries Commission, Newport, Oregon 97365, USA \\ ${ }^{3}$ NOAA Fisheries, Northwest Fisheries Science Center, Newport, Oregon 97365, USA
}

Keywords: Ichthyoplankton, trophic ecology, prey, Chinook salmon, California Current

Juvenile Chinook salmon feed primarily on late larval and early juvenile fishes when they enter coastal waters (Daly and Brodeur 2015). The late larval and early juvenile life stage of most marine fishes are difficult to sample effectively (Brodeur et al. 2011), which led us to explore alternative indices of potential fish prey abundance. The majority of marine fishes in the northern California Current (NCC) spawn in late winter and early spring (Brodeur et al. 2008). Winter-spawned fish larvae that grow and survive through spring provide a food base for juvenile coho, steelhead, and Chinook salmon during their first marine summer. Therefore, we used the winter ichthyoplankton biomass as a proxy for potential salmon food during this critical growth period (Daly et al. 2013).

The five most dominant fish prey consumed by juvenile yearling and subyearling Chinook salmon, and yearling coho salmon in May-September 1998-2010 were originally chosen as the taxa to calculate the winter ichthyoplankton biomass (i.e., Pacific sand lance, sculpins, smelts, northern anchovy, and rockfishes). Biomasses of these taxa were significantly correlated with adult salmon return abundance (Daly et al. 2013).

The ichthyoplankton data used for the index come from five stations sampled bi-weekly along the Newport Hydrographic (NH) line in January-March 1998-2019. The stations in the index are fixed and are located from 9.3 $\mathrm{km}$ offshore to just off the shelf at $46.3 \mathrm{~km}$ (Peterson et al. 2014). Rarely sampled ichthyoplankton taxa (present in $<2.5 \%$ of the samples) and rarely- (or never-) eaten taxa (e.g., myctophids) were omitted from the biomass index. With inconsistent station and bi-weekly sampling, the biomass of each taxon was first averaged by station within each month/year, then by each month/year, and finally by each year for an overall annual average for each taxon. The biomass of the five taxa was summed to get one annual value and ln-transformed and entered into a Principal Coordinate analysis (PCO) and the axis-1 scores from that analysis were used as the index for each year.

Ocean regimes of 'cold' and 'warm' were established based upon NOAA's Ocean Indicator stoplight chart where the mean of the ranks were divided into two ranked groups (lower rank half $=$ cold, higher rank half $=$ warm; https://www.nwfsc.noaa.gov/research/divisions/fe/estuarine/oeip/g-forecast.cfm\#TableSF-02).

During 'cold' regimes, the colder and more productive ocean conditions coincided with higher winter ichthyoplankton biomass and a community dominated by coastal fish larvae such as Pacific sandlance, smelts, and various sculpins, salmon showed higher marine survival (Daly et al. 2017). In contrast, during the warm ocean periods, the winter ichthyoplankton biomass was low and primarily comprised of offshore taxa such as rockfishes and winter-spawned northern anchovy. The five taxa index was a combination of both coastal and offshore taxa, which related well to salmon returns for the first 17 years the index was used.

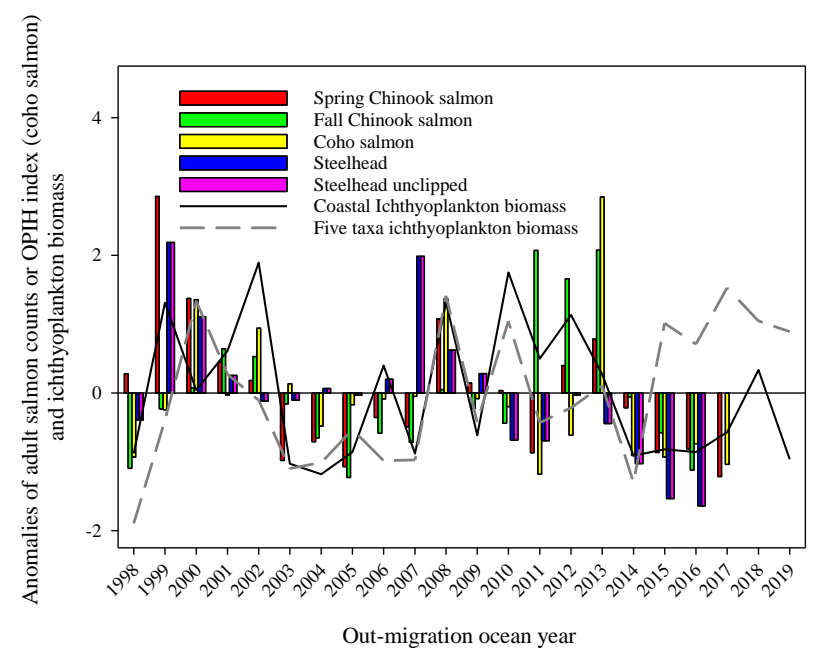

Fig. 1. Anomalies of the coastal and the five taxa ichthyoplankton biomass (no lag) and the adult salmon counts at Bonneville Dam lagged by time typically spent in ocean (two years for spring and fall Chinook salmon and steelhead and unmarked steelhead; and 1 year for coho salmon OPIH index).

All correspondence should be addressed to E. Daly. 
The marine heat wave and El Niño of 2014-2016 coincided with dramatic increases in sea surface temperatures through much of the Northeast Pacific $\left(+2.5^{\circ} \mathrm{C}\right.$; Bond et al. 2015), and this warming contributed to changes in the winter ichthyoplankton biomass and community not previously observed in the 22 -year time series (Auth et al. 2018). Since 2015, the biomasses of offshore ichthyoplankton taxa increased significantly along the NH line, and these taxa were increasingly consumed by juvenile salmon (Daly et al. 2017; Brodeur and Daly 2019). Moreover, the juvenile salmon that out-migrated in 2015 have returned as adults to the Columbia River one to two years later in much reduced numbers compared to previous years (Fig. 1).

Throughout the study period, one of the key taxa eaten during warmer ocean conditions was juvenile winterspawned rockfishes, which coincided with lower survival to adults than the years when the salmon consumed coastal prey such as Pacific sandlance (Daly and Brodeur 2015). Additionally, the community of taxa eaten by juvenile salmon and that comprising the winter ichthyoplankton cluster into similar warm and cold ocean regimes (Daly et al. 2017).
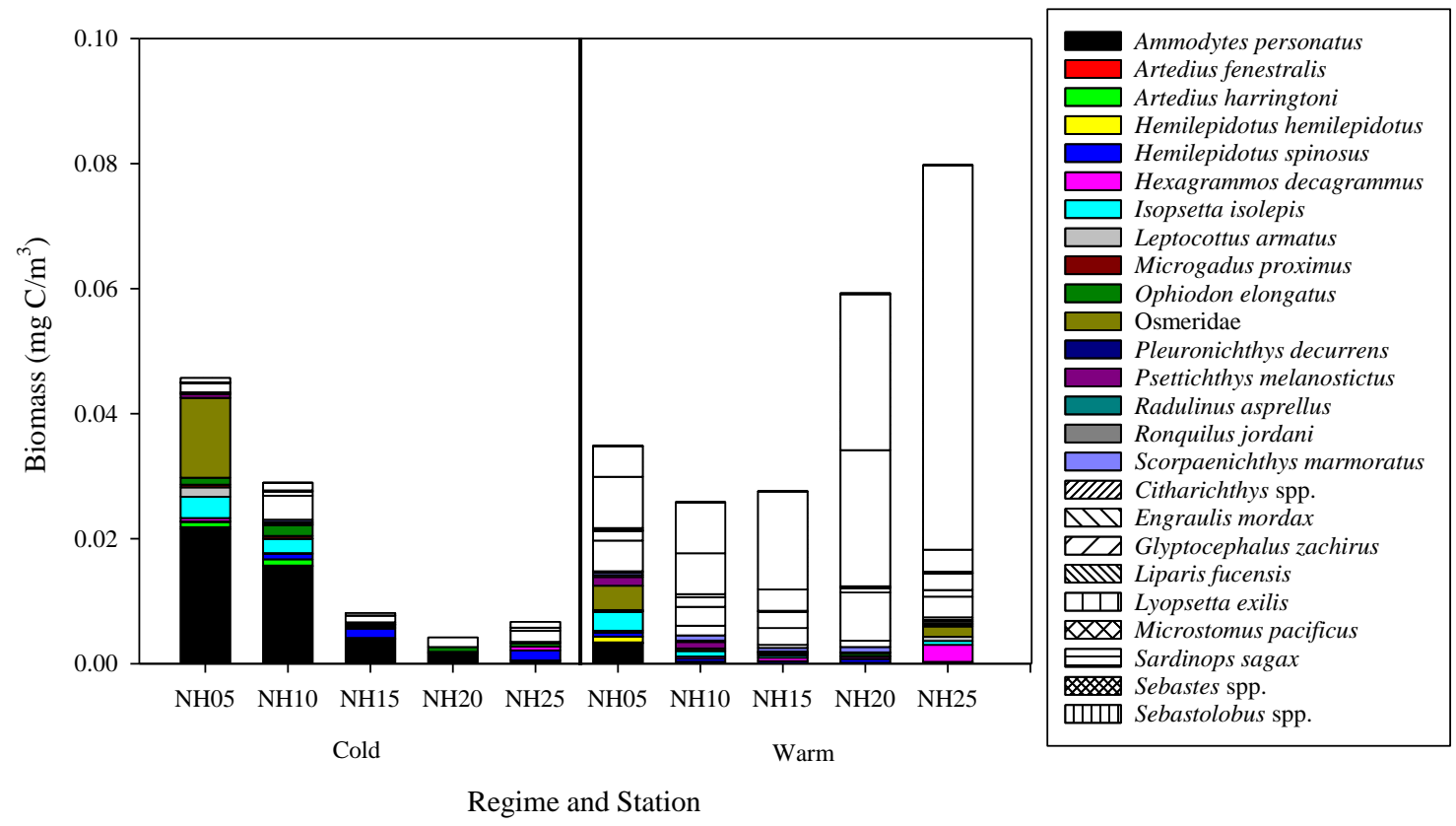

Fig. 2. Average biomass of ichthyoplankton by regime and Newport Hydrographic (NH) line stations of NH0525. Regime was established using the rank of the mean of the ranks divided into two groups (lowest half $=$ cold, higher half $=$ warm) from NOAA's NWFSC Ocean Ecosystem Indicator website: https://www.nwfsc.noaa.gov/research/divisions/fe/estuarine/oeip/g-forecast.cfm\#TableSF-02. Taxa listed in color are considered coastal, and taxa in white pattern are considered offshore.

When averaging all the ichthyoplankton taxa that salmon consume by ocean regime and station, there are distinct inshore to offshore changes in biomass. In the cold regime years, the highest mean larval fish biomass was inshore and was comprised of taxa known to be primarily coastal (Richardson and Pearcy 1977; Auth and Brodeur 2006; Auth 2011) with biomass declining in an onshore to offshore gradient (Fig. 2). In the warm ocean regime years, the highest mean larval fish biomass was found at the furthest offshore station $(46.3 \mathrm{~km})$, with biomass declining in an offshore to onshore gradient (Fig. 2).

In the last few years, the high biomass of winter ichthyoplankton has been out of phase with the salmon returns (Fig. 1). The five taxa index was a combination of cold and warm regime ichthyoplankton, which worked well until the recent marine heat wave that resulted in a substantial increase in the observed cross-shelf differences in ichthyoplankton biomass. Inclusion of offshore taxa in the original five taxa index did not qualitatively change the results, as the typical abundance of these taxa was low compared to the inshore taxa. However, the marine heat wave of 2014-2016 resulted in such high abundances of offshore taxa that their inclusion resulted in a noticeable change in the index. As such, we have modified the winter ichthyoplankton biomass index to include only the cold regime coastal ichthyoplankton taxa (see Fig. 2 for detailed list of the coastal and offshore taxa). In addition, the number of taxa included in the new Index of Coastal Prey Biomass (ICPB), and the coastal and offshore composition index, was expanded beyond the top five fish prey of juvenile salmon. 
Table 1. Biomass from 1998-2019 of coastal taxa sampled in January-March along the Newport Hydrographic line, the rank of the biomass from highest (1) to lowest (22), Axis-1 principal coordinate community analysis on the composition of coastal and offshore taxa by year, and the rank of the community from coastal taxa dominated $(1=$ most coastal taxa) to offshore taxa dominated $(22=$ most offshore taxa).

\begin{tabular}{|c|c|c|c|c|}
\hline Year & $\begin{array}{c}\text { Coastal biomass } \\
(\ln [(\mathrm{mg} \mathrm{C} \text { per } \\
\left.\left.1000 \mathrm{~m}^{3}\right)\right] \\
\end{array}$ & $\begin{array}{c}\text { Rank } \\
\text { biomass }\end{array}$ & $\begin{array}{c}\text { Coastal and offshore } \\
\text { taxa composition axis } 1 \\
\text { PCO scores }\end{array}$ & $\begin{array}{l}\text { Rank } \\
\text { PCO }\end{array}$ \\
\hline 1998 & 0.48 & 17 & -8.74 & 11 \\
\hline 1999 & 1.64 & 4 & -19.07 & 6 \\
\hline 2000 & 0.97 & 11 & -27.84 & 5 \\
\hline 2001 & 1.27 & 6 & -13.56 & 9 \\
\hline 2002 & 1.95 & 1 & -14.02 & 8 \\
\hline 2003 & 0.40 & 21 & -1.58 & 13 \\
\hline 2004 & 0.32 & 22 & 20.43 & 16 \\
\hline 2005 & 0.49 & 16 & 33.77 & 20 \\
\hline 2006 & 1.16 & 8 & -34.18 & 1 \\
\hline 2007 & 0.48 & 18 & 10.37 & 14 \\
\hline 2008 & 1.64 & 3 & -31.33 & 3 \\
\hline 2009 & 0.62 & 13 & -3.26 & 12 \\
\hline 2010 & 1.87 & 2 & 11.79 & 15 \\
\hline 2011 & 1.21 & 7 & -28.79 & 4 \\
\hline 2012 & 1.55 & 5 & -32.28 & 2 \\
\hline 2013 & 1.09 & 10 & -16.00 & 7 \\
\hline 2014 & 0.46 & 19 & -13.55 & 10 \\
\hline 2015 & 0.51 & 14 & 31.50 & 18 \\
\hline 2016 & 0.49 & 15 & 34.14 & 21 \\
\hline 2017 & 0.64 & 12 & 39.67 & 22 \\
\hline 2018 & 1.12 & 9 & 29.53 & 17 \\
\hline 2019 & 0.43 & 20 & 33.00 & 19 \\
\hline
\end{tabular}

Table 2. Linear model regression results of the adult counts at Bonneville Dam lagged two ocean years for spring and fall Chinook salmon and steelhead (outlier years 1999 and 2007 removed), and Oregon Production Index, Hatchery (OPIH) for coho salmon lagged one ocean year (outlier year 2013 removed) and the following indicators: the original five taxa winter ichthyoplankton biomass index, coastal taxa winter ichthyoplankton biomass, five taxa composition axis-1 principal coordinate analysis score, and coastal and offshore composition axis- 1 principal coordinate analysis score. Significant $(<0.05) P$ values and adjusted R-square values are listed. $P$ values $>0.05$ but $<0.1$ are listed in red, and non-significant relationships are listed as 'ns'. For adult salmon returns see: https://www.nwfsc.noaa.gov/research/divisions/fe/estuarine/oeip/ad-returns.cfm and http://www.fpc.org/web/apps/adultsalmon/Q_adultcounts_annualtotalsquery.php.

\begin{tabular}{|c|c|c|c|c|}
\hline Indicator & $\begin{array}{l}\text { Spring Chinook adult } \\
\text { returns 1998-2017 lag } \\
2 \mathrm{yr}\end{array}$ & $\begin{array}{l}\text { Coho OPIH 1998-2017 } \\
\text { (no yr 2013) lag } 1 \text { yr }\end{array}$ & $\begin{array}{l}\text { Fall Chinook salmon } \\
\text { adult returns 1998- } \\
2016 \text { lag } 2 \text { yr }\end{array}$ & $\begin{array}{l}\text { Steelhead adult returns } 1998-2016 \\
\quad \text { (no yr } 1999 \& 2007 \text { ) lag } 2 \text { yr }\end{array}$ \\
\hline Five taxa biomass & ns & ns & ns & ns \\
\hline $\begin{array}{l}\text { Coastal taxa } \\
\text { biomass }\end{array}$ & $0.02 ; 23.9 \%$ & 0.07 & $0.02 ; 24.5 \%$ & ns \\
\hline $\begin{array}{l}\text { Five taxa } \\
\text { composition score } \\
\text { Coastal and }\end{array}$ & $0.0006 ; 47.6 \%$ & $0.03 ; 21.3 \%$ & $0.0008 ; 46.7 \%$ & $0.02 ; 27.6 \%$ \\
\hline offshore taxa score & $0.001 ; 46.6 \%$ & 0.08 & $0.001 ; 43.9 \%$ & $0.01 ; 29.4 \%$ \\
\hline
\end{tabular}

Since 2014, the new ICPB has been below average with the exception of 2018 (which was more of an average year) and the coastal biomass index in 2019 was the 20th lowest in the 22-year time series (Table 1). The community composition of ichthyoplankton in 2019 was once again dominated by offshore taxa, with the community indicator suggesting poor food conditions for piscivorous juvenile salmon that out-migrate into the 
ocean in 2019 (Table 1). Adding the more recent data, our original biomass of the five taxa no longer shows a significant relationship to adult returns of Chinook and coho salmon or steelhead (Table 2). However, the ICPB is significantly correlated with yearling spring Chinook and subyearling fall Chinook salmon adult counts to Bonneville Dam. However, this relationship does not hold for coho salmon OPIH $(p=0.07)$. The community analysis (PCO axis 1 scores) of the ichthyoplankton composition with either the original five taxa or the composition of the coastal and offshore taxa were significant for all the salmon we examined, with the exception of coho salmon and the coastal and offshore taxa ( $p=0.08$; Table 2).

In conclusion, warm ocean conditions clearly affect both the biomass and the community composition of winter ichthyoplankton in the NCC. Winter ichthyoplankton, especially coastal taxa represented in the ICPB, are an important indicator of future food conditions for piscivorous juvenile salmon during a vulnerable and critical time in their life cycle. Survival of juvenile salmon that out-migrated into the ocean since the marine heat wave of 20142016 has uniformly been poor. Ichthyoplankton abundance and species composition in 2019 were similar to those observed during 2015-2018, suggesting a continuation of the poor salmon returns for at least the next several years.

\section{REFERENCES}

Auth, T.D. and R.D. Brodeur. 2006. Distribution and community structure of ichthyoplankton off the coast of Oregon, USA, in 2000 and 2002. Mar. Ecol. Prog. Ser. 319: 199-213.

Auth, T.D. 2011. Analysis of the spring-fall epipelagic ichthyoplankton community in the northern California Current in 2004-2009 in relation to environmental forcing factors. CalCOFI Rep. 52: 148-167.

Auth, T.D., Daly, E.A., Brodeur, R.D., and J.L. Fisher. 2018. Phenological and distributional shifts in ichthyoplankton associated with recent warming in the northeast Pacific Ocean. Glob. Chang. Bio. 24: 259272.

Bond, N. A., Cronin, M. F., Freeland, H., and Mantua, N. 2015. Causes and impacts of the 2014 warm anomaly in the NE Pacific. Geophys. Res. Lett. 42: 3414-3420. doi: 10.1002/2015GL063306

Brodeur, R.D., Peterson, W.T., Auth, T.D., Soulen, H.L., Parnel, M.M., and A.A. Emerson. 2008. Abundance and diversity of coastal fish larvae as indicators of recent changes in ocean and climate conditions in the Oregon upwelling zone. Mar. Ecol. Prog. Ser. 366: 187-202.

Brodeur, R.D., and E.A. Daly. 2019. Changing ocean conditions and some consequences for juvenile salmon feeding in coastal waters. N. Pac. Anadr. Fish Comm. Tech. Rep. 15. (Available at https://npafc.org)

Brodeur, R.D., Daly, E.A., Benkwitt, C.E., Morgan, C.A., and R.L. Emmett. 2011. Catching the prey: sampling juvenile fish and invertebrate prey fields of juvenile coho and Chinook salmon during their early marine residence. Fish. Res. 108: 65-73.

Daly, E.A., Auth, T.D., Brodeur, R.D., and W.T. Peterson. 2013. Winter ichthyoplankton biomass as a predictor of early summer prey fields and survival of juvenile salmon in the northern California Current. Mar. Ecol. Prog. Ser. 484: 203-217.

Daly, E.A., and R.D. Brodeur. 2015. Warming ocean conditions relate to increased trophic requirements of threatened and endangered salmon. PLoS ONE 10(12): e0144066. doi:10.1371/ journal.pone.0144066.

Daly, E.A., Brodeur, R.D., and T.D. Auth. 2017. Anomalous ocean conditions in 2015: impacts on spring Chinook salmon and their prey field. Mar. Ecol. Prog. Ser. 566: 169-182.

Peterson, W.T., Fisher, J.L., Peterson, J.O., Morgan, C.A., Burke, B.J., and K.L. Fresh. 2014. Applied fisheries oceanography: ecosystem indicators of ocean conditions inform fisheries management in the California Current ecosystem. Oceanogr. 27: 80-89.

Richardson, S.L. and W.G. Pearcy. 1977. Coastal and oceanic larvae in an area of upwelling off Yaquina Bay, Oregon. Fish. Bull. 75: 125-145. 